\title{
Polypeptide Pattern of Apple Tissues Affected by Calcium-related Physiopathologies
}

\author{
J. Val,* M.A. Gracia, A. Blanco, E. Monge and M. Pérez \\ Estación Experimental de Aula Dei, Consejo Superior de Investigaciones Científicas, \\ Apartado 202, 50080- \\ Zaragoza, Spain
}

Polypeptides from the apple pulp of Smoothee Golden Delicious and White Renete apples were resolved by 1-D denaturing sodium dodecyl sulphate polyacrylamide gel electrophoresis (SDS-PAGE). According to the electropherograms, there were lower concentrations of 88, 74, 70.6 and 47.5-42 kDa proteins in bitter pit spots. Proteins weighing 30 and $26 \mathrm{kDa}$ were rare in sound pulp but frequently appeared in pits and adjacent tissue. Finally, a novel $18 \mathrm{kDa}$ protein was found in bitter pit spots in both varieties, and also in chemically induced corky lesions either by magnesium infiltration or ammonium oxalate cortical injections. The available data suggested that the novel protein might be an inhibitor of pectinmethylesterase, a small heat stress protein (smHSP) or a product of the Ypr-10 gene family identified with 'Mal d 1', the main allergen of apples. To elucidate the possible smHSP nature of the $18 \mathrm{kDa}$, a set of apples were heated at $40{ }^{\circ} \mathrm{C}$ for $20 \mathrm{~h}$, developing this protein in both the oxidised tissue and in the adjacent.

Key Words: apple, proteins, polypeptides, bitter pit, corky spots, calcium

\section{INTRODUCTION}

Bitter pit, one of the most important physiological disorders in apple production (Malus $\mathrm{x}$ domestica Borkh) seems to be related to calcium deficiency and to an imbalance of other minerals (Ferguson and Watkins, 1989). According to recent studies, corky spots that develop during bitter pit have greater concentrations of calcium, magnesium and potassium, greater polyphenol oxidase activity and lower concentrations of all carbohydrates (Val, 2003).

Although these processes may pose nutritional risks, there is no reliable way to predict when metabolic processes will lead to the development of bitter pit. The symptoms appear to be the result of important changes in the physiology and composition of the affected tissues, including ultrastructure (Simons and Chu, 1980), mineral nutrients (Aznar, 2001; Aznar et al., 2001), organic acids (Steenkamp et al., 1983) and, most probably, protein patterns.

Burmeister and Dilley (1994) suggested a specific role for $\mathrm{Ca}^{2+}$ and $\mathrm{Mg}^{2+}$ in bitter pit development. These authors speculated that extracellular $\mathrm{Mg}^{2+}$ supplied by infiltration may

\footnotetext{
*To whom correspondence should be sent

(email: jval@eead.csic.es).

Received 22 July 2005; revised 26 January 2006.
} 
affect the supply of $\mathrm{Ca}^{2+}$ in the apoplast of apple fruit influencing the ability of cells to regulate cytosolic $\mathrm{Ca}^{2+}$, either by perturbation of a voltage-regulated $\mathrm{Ca}^{2+}$ channel or by displacing $\mathrm{Ca}^{2+}$ from ionic binding sites in the apoplast. This could interfere with the role ofCa2+ as a second messenger involving a $\mathrm{Ca}^{2+}$-ATPase, $\mathrm{Ca}^{2+} /$ calmodulin-linked phosphorylation of an enzyme, or a regulatory protein involved in cellular homeostasis, or metabolism. They suggested that $\mathrm{Mg}^{2+}$ exacerbates the potential for apple fruit to initiate the chain of reactions involved in expressing this $\mathrm{Ca} 2$-related disorder.

The amount of protein in apples, like most fresh fruits and vegetables, is quite low, representing approximately $0.2 \%$ of their fresh weight (Wills et al., 2001). Nevertheless, fruit protein is a key component of nuclear and cytoplasmic structures (determining and maintaining cellular organisation) as well as the enzymes involved in metabolism during growth, development, maturation and postharvest life.

Small heat shock proteins are produced ubiquitously in prokaryotic and eukaryotic cells upon heating. Production and accumulation of smHSP in response to environmental stresses and developmental stimuli have been correlated with stress tolerance (Sun et al., 2002). These proteins are believed to confer tolerance to heat and other stresses by protecting proteins from irreversible denaturation and breakdown also in apple fruits (Wünsche et al., 2004).

In fruits, the protein patterns obtained by electrophoresis are generally highly specific, and can be used for the analytical differentiation of species and varieties (Belitz and Grosch, 1999).

There are few studies on the composition of apple tissues affected by corky physiopathologies and we have not found published data about the protein pattern of these tissues. The authors aimed to ascertain polypeptide composition of apple pulp affected by bitter pit and other corky tissues, developed under chemical treatments (magnesium infiltration and oxalate injections), compared with adjacent sound tissue and pulp from healthy fruit.

\section{MATERIALS AND METHODS}

\section{Plant Material}

Sound and bitter pit affected pulp and chemically induced cork spots were extracted from the apple varieties: Smoothee Golden Delicious, from a commercial orchard of the ALM Group located in Quinto de Ebro (Zaragoza, northeastern Spain) and White Renete from Canada, from the apple germoplasm collection of the Estación Experimental de Aula Dei.

\section{Induction of Corky Lesions in Apple}

\section{Vacuum Infiltration of Mg Salts}

The method as described by Retamales et al. (2000) is useful to predict bitter pit incidence before harvest. Fruits are vacuum infiltrated for $2 \mathrm{~min}$ in $0.05 \mathrm{M} \mathrm{MgCl}_{2}$ (with $0.4 \mathrm{M}$ sorbitol $/ 0.01 \%$ Tween 20 ) and held for 14 days at room temperature. After this, the fruits 
susceptible to bitter pit may develop bitter pit like symptoms. In this work, after the 2 min of vacuum, fruits of Smoothee Golden Delicious' cvs. were left submerged for $15 \mathrm{~min}$ at atmospheric pressure. By this slight modification, the effectivity of the test was enhanced, allowing the development of pitted tissue before 7 days.

\section{Ammonium Oxalate}

Several injections with $100 \mu \mathrm{L}$ ammonium oxalate $(0.4 \% \mathrm{w} / \mathrm{v})$ were made by an insulin syringe at $0.5 \mathrm{~cm}$ deep in the pulp of 'Smoothee Golden Delicious' apples. After $48 \mathrm{~h}$ at room temperature, large corky lesions are clearly visible inside the apple mesocarp.

\section{Heat Treatment}

Three sets of 15 'Smoothee Golden Delicious' apples, homogeneous in size and colour were heated in the dark in a heat cabinet at $40{ }^{\circ} \mathrm{C}$ and $50 \%$ relative humidity. This treatment was maintained for $72 \mathrm{~h}$, after which the fruits were removed and left to cool to room temperature for $4 \mathrm{~h}$.

\section{Extraction of Corky Areas}

Pitted tissue was surgically removed by carefully separating the spots from the surrounding sound tissue and epidermis. Each sample comprised a group of pits from different apples to obtain a representative fraction of the different tissues. Samples were then immediately placed in liquid nitrogen and stored at $-80{ }^{\circ} \mathrm{C}$. Sound tissue from pitted apples and non-affected fruits was also extracted and analysed separately.

The frozen samples were ground with a pestle and mortar in a buffer described by del Valle et al. (1998) which consisted of 0.2M phosphate (pH 7.0), 1\% PVP and 0.5\% Triton $\mathrm{X} 100$, using $1.5 \mathrm{~mL}$ per $1 \mathrm{~g}$ of sample.

\section{Denaturing Polyacrylamide Gel Electrophoresis}

Proteins were separated by vertical denaturing zone electrophoresis in polyacrylamide gels (PAGE) using a Mini-protean 3 system (BioRad) following Laemmli (1970). Gels had two isocratic phases, both containing 1\% SDS. The stacking and resolving gels contained 5\% and $12-15 \%$ acrylamide, respectively.

The total amount of protein was quantified using the colorimetric method described in Markwell et al. (1981).

Coomasie Staining of the slab gels was performed in a methanol, glacial acetic acid and distilled water solution (4:0.7:5.3 v/v) with $3 \mathrm{mM}$ Coomasie Brilliant Blue R-250.

Silver staining of gels was performed according to Shevchenko et al. (1996). The gel was fixed in 50\% methanol, $5 \%$ acetic acid in water for $20 \mathrm{~min}$. Afterwards, it was washed for $10 \mathrm{~min}$ with $50 \%$ methanol and for another $10 \mathrm{~min}$ with water. The gel was sensitised by $0.02 \%$ sodium thiosulphate for $1 \mathrm{~min}$, and rinsed with distilled water for $1 \mathrm{~min}$ twice. Then, the gel was submerged in $0.1 \%$ silver nitrate solution and incubated for $20 \mathrm{~min}$ at $4^{\circ} \mathrm{C}$. After 
incubation, the gel was rinsed twice with water for $1 \mathrm{~min}$ and developed in a solution containing $0.05 \%$ formaldehyde in $2 \%$ sodium carbonate with intensive shaking. When the developer turned yellow, it was replaced with a fresh solution until the desired intensity of bands was achieved. The gel was washed with 5\% acetic acid and stored in $1 \%$ acetic acid.

The molecular weights of each band separated by SDS-PAGE were determined using the images from more than 30 gels each loaded with eight tracks of sample.

\section{RESULTS AND DISCUSSION}

Fruit tissues contain cytoplasmic proteins that are vital to cell processes and cell structure. Under denaturing conditions, polyacrylamide gel electrophoresis (PAGE) can separate polypeptides from biological samples based on molecular size. This technique can provide information about differences in protein patterns from different apple fruit tissues.

The dark arrows in the electropherogram (Figure 1) corresponded to the main bands in the three types of tissues. Sound apples from the two varieties showed great similarities in the protein patterns. The most representative proteins were 64, 50.8, 40, 37.7, 36 and $19.2 \mathrm{kDa}$. Proteins weighing 64 and $36 \mathrm{kDa}$ appeared in all tissues but had lower optical density in pits.

Other bands shown with solid continuous lines in Figure 1 (such as 33.4 and $31.6 \mathrm{kDa}$ ) could be important in bitter pit, although they are slightly visible in sound apple and in sound areas adjacent to the pits.

The bands at $88,47.5,42 \mathrm{kDa}$ were less dense in the pitted material. However, the $98.3 \mathrm{kDa}$ protein was apparent in both areas of the affected fruit and less intense in the sound apple pulp. The 70.6 and $74 \mathrm{kDa}$ proteins did not appear in pit tissue, but they were found in the sound apple tissue and in the areas adjacent to the pits.

The 26 and $30 \mathrm{kDa}$ proteins were almost absent in the sound apples but present in the affected fruit (pits and adjacent pulp). As opposed to previous studies (Nicolas, 1994; Poovaiah and Reddy, 1993; Lay-Yee et al., 1990) the bands found by the authors seemed to correspond to proteins of well-known function. The 26 and $33.4 \mathrm{kDa}$ proteins could correspond to different polyphenoloxidase isozymes and the 42 and $47.5 \mathrm{kDa}$ proteins to polygalacturonase and the $40 \mathrm{kDa}$ protein to peroxidase. Similarities have been found among proteins with well-known functionality and the 19.2, 30 and $40 \mathrm{kDa}$ bands of those gels.

The protein pattern of the pits observed in both cultivars was very similar (Figure 1). Most notably, an $18 \mathrm{kDa}$ protein was only found in affected tissues. Giovane et al. (1995) purified an $18 \mathrm{kDa}$ protein in kiwi and suggested that it inhibited pectinmethylesterase. This would make sense in pits if the inhibitor has a protective role in the cellular wall. Those authors proposed that the protein came from a $30 \mathrm{kDa}$ inactive precursor, which could be transformed by protease into an active protein during maturation.

The correlation between Mg-induced pits and development of bitter pit in storage was first proposed by Burmeister and Dilley (1994), other workers have demonstrated that magnesium infiltration of fruits has shown high bitter pit predictive capacity for different cultivars, locations, seasons and sampling dates (Retamales et al., 2000). Applying this method, with the modification already explained, pits were induced, which, after 
solubilisation and further electrophoresis, also developed a protein, corresponding to the $18 \mathrm{kDa}$ molecular weight, both in the affected and in the adjacent sound tissue (Figure 2).

Steenkamp et al. (1983) found high oxalate and citrate concentrations in bitter pit areas. By vacuum infiltration of oxalate solutions in apples these authors found damages in the middle lamellae of the fruit cells similar to those found in the naturally occurring pits. The authors tried to reproduce the experiment in their working conditions but they did not succeed in inducing the development of corky pits. However, by direct subdermical injections of a $0.4 \%$ ammonium oxalate solution, a clear external manifestation could be detected after $48 \mathrm{~h}$, corresponding to severe damage inside the pulp, that also accumulated calcium and magnesium as the naturally occurring pits do (data not shown).

The silver stained eletropherogram of the oxalate induced spots and the adjacent sound tissue reveals the similarity between the protein pattern of these tissues and that of natural pits. This correspondence includes the $18 \mathrm{kDa}$ protein, which appeared both in corky tissues and in the adjacent pulp, but not in the pulp from non treated apples (Figure 3).

According to the available information, and in the context of defining symptoms of physiopathologies as a consequence of oxidative stress, the $18 \mathrm{kDA}$ protein could also be associated with small heat shock proteins (Tadeo, 2000). Drought, salinity, cold, heat and metals induce the synthesis of these proteins that have been identified in animals, microorganisms and plants. They actively participate in the cellular response to heat and other stresses. The smHSP with molecular weights ranging from 15 to $42 \mathrm{kDa}$, act as chaperons when bounded to denatured proteins to prevent irreversible association with other proteins and the accumulation of insoluble aggregates. They also promote the proper folding of proteins once stress has disappeared.

Ritenour et al. (2001) induced in several apple cultivars the development of 17 new proteins in the 15-29 kDa rank following a heat treatment of $40{ }^{\circ} \mathrm{C}$ for $4 \mathrm{~h}$. In order to explain the link between smHSP and the $18 \mathrm{kDa}$ protein by heat treatments, the Smoothee Golden Delicious apples were heated at $45{ }^{\circ} \mathrm{C}$ for $20 \mathrm{~h}$. Large portions of the fruit were oxidised following this treatment, while the flesh colour turned brown, the rest of the pulp remained apparently unaffected. The electrophoretic run of these samples was performed in $15 \%$ polyacrilamide to increase the resolution of the gel in the low molecular weight range and silver stained to enhance the sensitivity. In Figure 4, can be clearly observed the development of an $18 \mathrm{kDa}$ protein in the apples submitted to heat, even in pulp without visible symptoms, which did not appear in the track corresponding to non-heated fruits. This seemed to be a response to heat stress, reinforcing the hypothesis of the smHSP nature of this $18 \mathrm{kDa}$ protein.

The smHSP are not the only proteins that plants express under stressful situations. Pathogen-related proteins (PR) are polypeptides expressed by genes activated by pathogens, wounds or environmental stress (Ebner and Breiteneder, 2002). The PRs are classified in 14 families, including PR-10 that occurs in fruits and vegetables, and is made up of proteins homologous to the main allergen of birch pollen 'Bet v 1'. Interestingly, the main allergen of apples, known as 'Mal d 1', is an $18 \mathrm{kDa}$ protein that causes type I allergies in patients sensitive to pollen from trees. They share epitopes with 'Bet $\mathrm{v} 1$ ' and, in addition, react with the serum extracted from sensitive allergic individuals. The amount of $18 \mathrm{kDa}$ apple allergen detected by Puhringer et al. (2000) depends on the cultivar and degree of maturity of the fruit and seems to increase during storage. 
In addition to describing the protein pattern of tissues from bitter pit affected apples, the authors have found an $18 \mathrm{kDa}$ protein that only appears in the spots in bitter pit samples from Smoothee Golden Delicious and White Renete of Canada. The authors have also identified this protein in other types of corky spots, such as those artificially induced by magnesium infiltration and localised oxalate injections. The appearance of this very protein in heated apples could indicate that this is a smHSP polypeptide. Determining the nature of this protein will help to understand the events involved in the development of calcium-related physiopathologies in apples.

\section{ACKNOWLEDGEMENTS}

This work was supported by research grants AGL2004-04305/AGR (Plan Nacional de Recursos y Tecnologías Agroalimentarias) and PM017/2004 (Gobierno de Aragón).

\section{REFERENCES}

Aznar Y. (2001). Caracterización fisiológica del bitter pit: aspectos nutricionales, fenológicos y métodos de diagnóstico. PhD Thesis: Department of Biochemistry and Molecular and Cellular Biology, University of Zaragoza, Zaragoza, Spain.

Aznar Y., Cortés E., Blanco A. and Val J. (2001). Composición aniónica y catiónica de las manchas de bitter pit en manzanas de tipo golden. Actas de Horticultura 29: 462-470.

Belitz H.D. and Grosch W. (1999). Food Chemistry. Berlin, Germany: Springer-Verlag.

Burmeister D.M. and Dilley D.R. (1994). Correlation of bitter pit on Northern Spy apples with bitter pit-like symptoms induced by $\mathrm{Mg}^{2+}$ salt infiltration. Postharvest Biology and Technology 4: 301-308.

del Valle J.M., Aránguiz V. and León H. (1998). Effects of blanching and calcium infiltration on PPO activity, texture, microstructure and kinetics of osmotic dehydration of apple tissue. Food Research Internacional 31: 557-569.

Ebner C. and Breiteneder H. (2002). A survey of plant food allergens. Allergologie 25: 527533.

Ferguson I.B. and Watkins C.B. (1989). Bitter pit in apple fruit. Horticultural Reviews 11: 289-355.

Giovane A., Balestrieri C., Quagliuolo L., Castaldo D. and Servillo L. (1995). A glycoprotein inhibitor of pectin methylesterase in kiwi fruit. Purification by affinity chromatography and evidence of ripeningrelated precursor. European Journal of Biochemistry 233: 926-929.

Laemmli U.K. (1970). Cleavage of structural proteins during the assembly of the head of bacteriophage T4. Nature 227: 680-685.

Lay-Yee M., DellaPenna D. and Ross G.S. (1990). Changes in mRNA and protein during ripening in apple fruit Malus domestica Borkh. cv. Golden Delicious. Plant Physiology 94: 850-853. 
Markwell M.A.K., Haas S.M., Tolbert N.E. and Bieber L.L. (1981). Protein determination in membrane and liproprotein samples, manual and automated procedures. Methods in Enzymolgy 72: 296-303.

Nicolas J.J. (1994). Enzymatic browning reactions in apple and apple products. Critical Reviews in Food Science and Nutrition. 34: 109-157.

Poovaiah B.W. and Reddy A.S.N. (1993) Calcium and signal transduction in plants. Critical Reviews in Plant Sciences 12: 185-211.

Puhringer H., Moll D., Hoffmann-Sommergruber K., Watillon B., Katinger H. and Laimer da Camara Machado M. (2000). The promoter of an apple Ypr10 gene, encoding the major allergen Mal d 1, is stress- and pathogen-inducible. Plant Science 152: 35-50.

Retamales J.B., Valdes C., Dilley D.R., Leon L. and Lepe V.P. (2000). Bitter pit prediction in apples through Mg infiltration. Acta Horticulturae 512: 169-179.

Ritenour M.A., Kochhar S., Schrader L.E., Hsu T.P. and Ku M.S.B. (2001). Characterization of heat shock protein expression in apple peel under field and laboratory conditions. Journal of the American Society for Horticultural Science 126: 564-570.

Shevchenko A., Wilm M., Vorm O. and Mann M. (1996). Mass spectrometric sequencing of proteins from silverstained polyacrylamide gels. Analytical Chemistry 68: 850-858.

Simons R.K. and Chu M.C. (1980) Scanning electron microscopy and electron microprobe studies of bitter pit in apples. In: Atkinson D., Jackson J.E., Sharples R.O. and Waller W.M. (eds), Mineral Nutrition of Fruit Trees. London: Butterworths, pp. 57-70.

Steenkamp J., Terblanche J.H. and de Villiers O.T. (1983). The role of organic acids and nutrient elements in relation to bitter pit in golden delicious apples. Acta Horticulturae 138: $35-42$.

Sun W.N., Van Montagu M. and Verbruggen N. (2002). Small heat shock proteins and stress tolerance in plants. Biochimica et Biophysica Acta-Gene Structure and Expresión 1577: 19.

Tadeo F.R. (2000). Fisiología de las plantas y el estrés. In: Azcón-Bieto J. and Talón M. (eds), Fundamentos de fisiología vegetal. Madrid, Spain: McGraw Hill/Interamericana de España, S.A.U. y Edicions Universitat de Barcelona, pp. 481-498.

Val J. (2003). Avances recientes en la investigación del bitter pit. Vida Rural 165: 42-44.

Wills S., Lee T.H., McGlasson W.B., Hall E.G. and Graham D. (2001). Fisiología y manipulación de frutas y hortalizas en posrecolección. Zaragoza, Spain: Editorial Acribia.

Wünsche J.N., Bowen J., Ferguson I., Woolf A. and McGhie T. (2004). Sunburn on apples causes and control mechanisms. Acta Horticulturae 636: 631-636. 


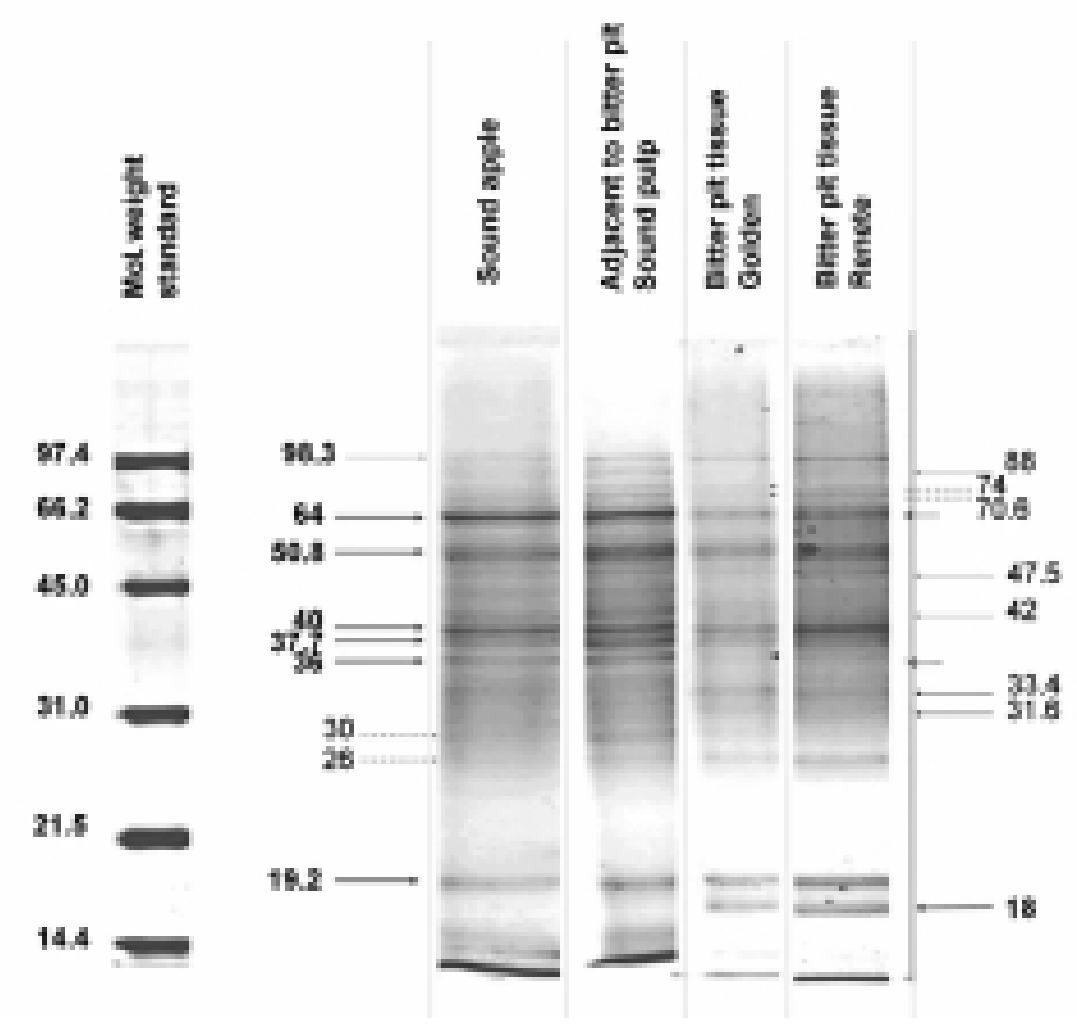

Figure 1. Coomasie Blue stain of protein patterns from the pits of Golden and Reneta apples, adjacent sound tissue and pulp from a sound Smoothee Golden Delicious.

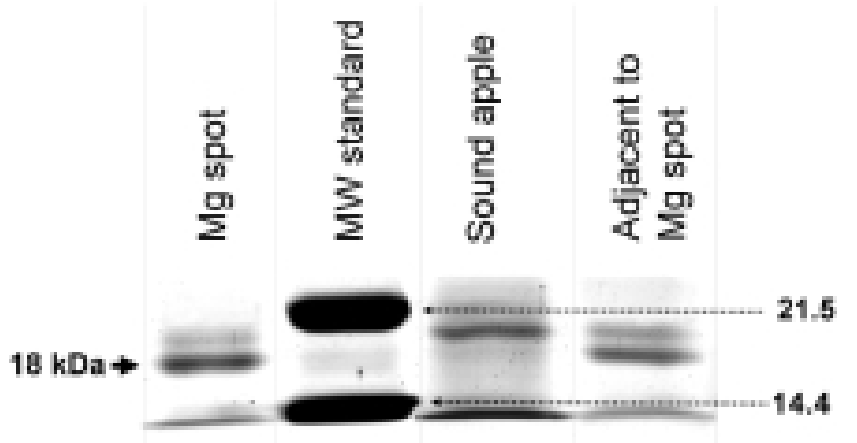

Figure 2. Coomasie Blue stain, in the lowest molecular range of the gel, of proteins from the $\mathrm{Mg}$ infiltration induced pits on Smoothee Golden Delicious apples, adjacent sound tissue and pulp from a sound fruit. 


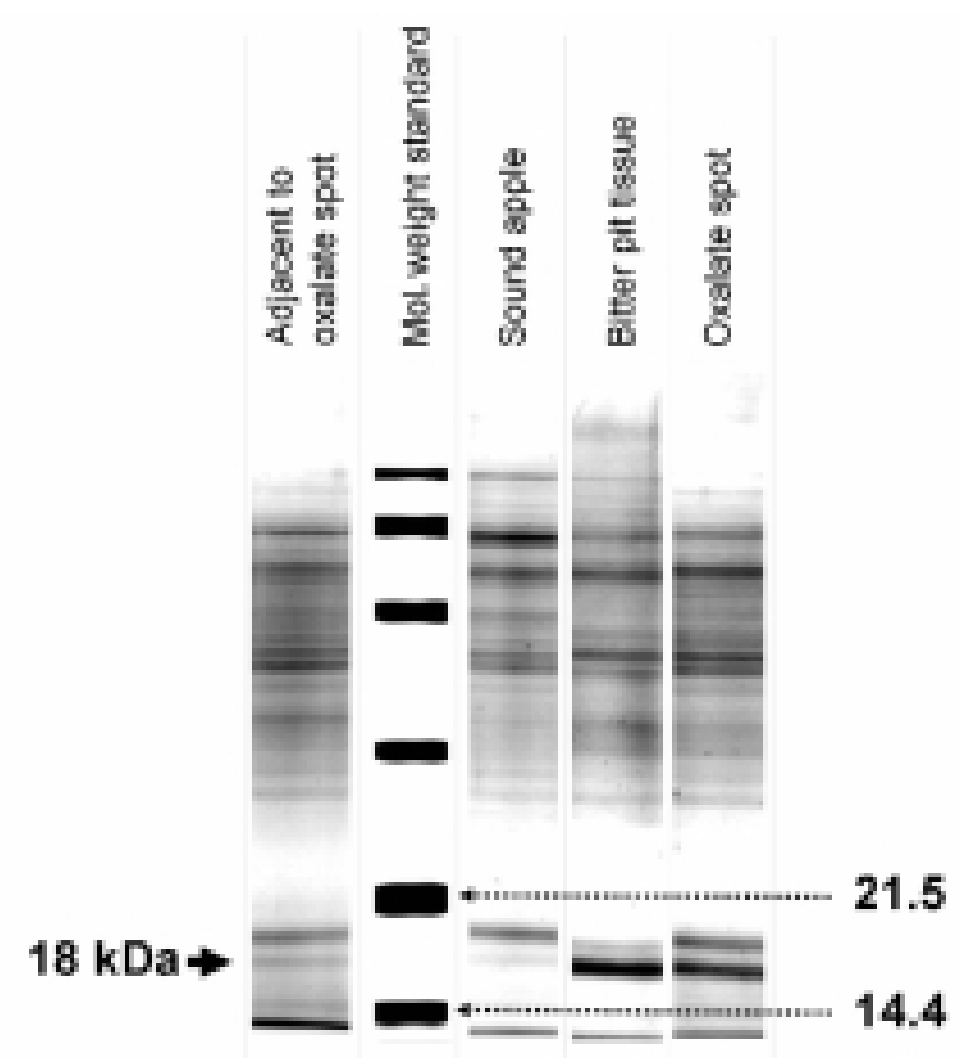

Figure 3. Silver staining of SDS-(15\%) polyacrilamide of protein patterns from bitter pit areas, oxalate induced spots and adjacent sound tissue from Smoothee Golden Delicious apples. 